\title{
Inhibition of cardiac CaMKII to cure heart failure: step by step towards translation?
}

\author{
Friederike Cuello $^{1,2} \cdot$ Kristina Lorenz ${ }^{3,4,5}$
}

Received: 12 September 2016/Accepted: 12 September 2016/Published online: 28 September 2016

(c) The Author(s) 2016. This article is published with open access at Springerlink.com

During the past decade, calcium/calmodulin-dependent protein kinase II (CaMKII) has emerged as a central culprit in the development of cardiac arrhythmia and heart failure. This has been supported by a plethora of studies using transgenic mouse models and pharmacological CaMKII inhibitors and peptides. However, the final proof that CaMKII inhibition improves dysfunction of a failing heart is still pending. In this issue, Kreusser et al. [19] demonstrated that knockdown of the two key cardiac CaMKII isoforms after the onset of hemodynamic stress succeeds to reverse maladaptive cardiac remodeling processes. Their study is an important step in translating CaMKII inhibition from bench to bedside for heart failure therapy.

This comment refers to the article available at doi:10.1007/s00395016-0581-2.

\section{Friederike Cuello}

f.cuello@uke.de

$\bowtie$ Kristina Lorenz

kristina.lorenz@isas.de

1 Department of Experimental Pharmacology and Toxicology, Cardiovascular Research Center, University Medical Center Hamburg-Eppendorf, Martinistrasse 52, 20246 Hamburg, Germany

2 DZHK (German Center for Cardiovascular Research), Partner Site Hamburg/Kiel/Lübeck, University Medical Center Hamburg-Eppendorf, Martinistrasse 52, 20246 Hamburg, Germany

3 Comprehensive Heart Failure Center, Versbacher Strasse. 9, 97078 Würzburg, Germany

4 West German Heart and Vascular Center Essen, University Hospital Essen, Hufelandstrasse 55, 45147 Essen, Germany

5 Leibniz-Institut für Analytische Wissenschaften-ISAS-e.V., Bunsen-Kirchhoff-Strasse 11, 44139 Dortmund, Germany
CaMKII is a multifunctional protein kinase that plays a pivotal role in cardiac (patho) physiology [27, 40]. It represents a nodal point in the regulation of intracellular $\mathrm{Ca}^{2+}$ handling, ion channels and gene transcription. As the description "multifunctional" and "nodal point" implies, this kinase is intertwined into a complex cellular signaling network and thus tricky to manipulate therapeutically: CaMKII activity is regulated by posttranslational modifications that allow maintenance of kinase activity independently of $\mathrm{Ca}^{2+} /$ calmodulin-binding. Amongst those autophosphorylation $[16,26,45]$, oxidation $[2,7,13,32$, 45], $O$-linked $N$-acetylglucosamination [9] and $S$-nitrosylation $[8,12]$ have been described to date. CaMKII has various cellular targets in $\mathrm{Ca}^{2+}$ homeostasis some of which are the ryanodine receptor $[26,34,39,41]$, phospholamban $[5,18]$ and cardiac myosin-binding protein $\mathrm{C}$ [37]. Furthermore, CaMKII impacts on L-type $\mathrm{Ca}^{2+}$ channel (LTCC) currents and LTCC expression [40], on expression of the $\mathrm{Na}^{+} / \mathrm{Ca}^{2+}$ exchanger $[10,23]$ and the sarcoplasmic reticulum $\mathrm{Ca}^{2+}$ ATPase 2a (SERCA2a) $[5,23,42]$ as well as on gene transcription via the regulation of calcineurin and class II histone deacetylase isoforms [3, 24]. CaMKII is ubiquitously expressed, with $\alpha$ and $\beta$ as predominant isoforms in the brain, where they are important for neuronal function and cognitive memory. CaMKII $\gamma$ and $\delta$ are the key isoforms expressed in the heart. Particular attention has been paid to two CaMKII $\delta$ splice variants in the heart, $\mathrm{CaMKII} \delta_{\mathrm{B}}$ and CaMKII $\delta_{\mathrm{C}}$. CaMKII $\delta_{\mathrm{B}}$ has an 11 amino acid nuclear localization sequence that is absent in CaMKIII $\delta_{\mathrm{C}}$. Studies performed in splice-variant-specific knockout mouse models have attributed a protective functional role to $\mathrm{CaMKII} \delta_{\mathrm{B}}$. Thus, cellular localization seems to participate in CaMKII isoform-specific pathophysiological roles $[4,5,28,44]$.

Despite of the physiological importance of CaMKII, for e.g,. excitation-contraction coupling, isoproterenol-induced 
heart rate adaptation, cognitive memory and neural plasticity functions, inhibition of CaMKII as a therapeutic strategy in different forms of cardiac disease increasingly solidifies. Cardiac expression and activity of CaMKII have been shown to be increased in cardiac disease and more importantly also augments the incidence of cardiac disease, particularly arrhythmia, atrial fibrillation and progressive cardiac remodeling $[6,15,17,21,27,29,42,43]$. Proof-ofconcept studies in mice and isolated human cardiac myocytes have successfully demonstrated the benefit of CaM$\mathrm{KII} \delta$ and CaMKII $\gamma$ inhibition in several pathological cardiac conditions. However, translation of these convincing preclinical "prevention" studies into therapeutic strategies or even a preclinical "therapy/rescue" study seems rather challenging.

Difficult hurdles that have to be envisaged to selectively target disease-specific kinase functions $[22,38]$ to ultimately achieve clinical translatability are the design of (1) appropriate cardiac-specific gene therapy approaches for the expression of inhibitory peptides, proteins or knockdown-vectors or (2) isoform-specific, orally administrable, non-CNS penetrating small compound inhibitors. The peptides and compounds that have been developed thus far have been shown to exert off-target effects, which include the inhibition of potassium channels (KN-93; [14]), blockade of anchoring proteins and substrates (CaMKIIN and CaMKIINtides; $[25,30]$ ) and in case of ATP-competitive compounds the inhibition of other kinases (SMP114; [30]), or they are orally not bioavailable [30].

Pharmacological CaMKII inhibitors as well as the transgenic mouse models have been extremely valuable for dissecting the functional roles of CaMKII in cells and in vivo, but they remain experimental tools (reviewed in [29, 30, 42]). And, the question, whether CaMKII inhibition-in an ideal "off-target free" setting-has the potential to ameliorate cardiac remodeling and cardiac function after the onset of heart failure, is still unanswered. With the tools available, this question was not yet appropriately addressable. Kreusser et al. [19] have now developed genetic mouse models with inducible CaMKII $\delta$ and $\gamma$ knockdown to address exactly this issue: "Is CaMKII inhibition able and sufficient to rescue a failing heart?" And the answer from this mouse study is "Yes"! This is the first time that CaMKII inhibition has been tested in a "therapy/rescue" situation.

In their study, the authors use mouse models that are based on a cardiac-specific conditional knockdown of CaMKII $\delta$ and $\gamma$ by tamoxifen or by Cre-recombinase overexpression via adeno-associated viral vectors. In both approaches, the development of interstitial fibrosis and contractile defects in response to chronic left ventricular pressure overload (induced by transverse aortic constriction) was decelerated and even slightly reversed. This study shows convincingly that inhibition of cardiac CaMKII expression is a promising goal for the improvement of chronic heart failure therapy. Thus, the effort has to be taken and to be enforced to realistically name CaMKII a clinically relevant target.

However, it will still be a long and arduous way to implement clinical CaMKII inhibition for heart failure therapy. Due to the high homology between existing CaMKII isoforms and their physiological roles, CaMKII targeting strategies have to take cardiac and isoform specificity into account. In this context, the establishment of a gene therapy approach seems "easier" than the development of pharmacological inhibitors. Also, gene therapy studies in large animals or even patients have already been tested for S100A1, SERCA2a and adenylyl cyclase 6 $[1,11,20,31,33,35,36]$. SERCA2a gene therapy has already reached clinical phase IIb studies, but then failed due to insufficient delivery of viral particles to the heart. Nevertheless, these studies delivered proof of the general concept, and have at the same time revealed the difficulties that still need to be overcome. For the development of small pharmacological compounds, even more challenges have to be faced: As mentioned before, the CaMKII family comprises highly homologous isoforms and splice variants, which makes selective pharmacological targeting of a specific isoform or splice variant rather impossible. At this point, the manipulation of certain downstream targets of CaMKII comes into play. Thus far, however, it is not clear, which of the targets has the major impact on cardiac disease progression or if there are even targets of different importance in different cardiac diseases. It will be a major effort to dissect the impact of the CaMKII-mediated molecular effects in different disease scenarios to really be able to predict the therapeutic benefit of target specific CaMKII inhibition. To promote the design of an appropriate pharmacological compound, we will certainly have to disentangle physiological from the pathological CaMKII functions. With their study Kreusser et al. [19] have clearly demonstrated that CaMKII inhibition is the right avenue to tread for significant benefit in heart failure therapy in the future.

Acknowledgments This work was supported by the German Ministry of Research and Education (German Centre for Cardiovascular Research, F.C.; Comprehensive Heart Failure Center Würzburg, K.L.), the Deutsche Forschungsgemeinschaft (CU 53/2-1 to F.C.; Sonderforschungsbereich SFB688, TPA17 to K.L.), the Werner-OttoStiftung (F.C.), and by the Ministry for Innovation, Science and Research of the Federal State of North Rhine-Westphalia (K.L.).

Open Access This article is distributed under the terms of the Creative Commons Attribution 4.0 International License (http://crea tivecommons.org/licenses/by/4.0/), which permits unrestricted use, distribution, and reproduction in any medium, provided you give appropriate credit to the original author(s) and the source, provide a link to the Creative Commons license, and indicate if changes were made. 


\section{References}

1. Aguero J, Ishikawa K, Hadri L, Santos-Gallego CG, Fish KM, Kohlbrenner E, Hammoudi N, Kho C, Lee A, Ibáñez B, GarcíaAlvarez A, Zsebo K, Maron BA, Plataki M, Fuster V, Leopold JA, Hajjar RJ (2016) Intratracheal gene delivery of SERCA2a ameliorates chronic post-capillary pulmonary hypertension. JACC 67:2032-2046. doi:10.1016/j.jacc.2016.02.049

2. Anderson ME (2015) Oxidant stress promotes disease by activating CaMKII. J Mol Cell Cardiol 89:160-167. doi:10.1016/j. yjmcc.2015.10.014

3. Backs J, Song K, Bezprozvannaya S, Chang S, Olson EN (2006) CaM kinase II selectively signals to histone deacetylase 4 during cardiomyocyte hypertrophy. J Clin Invest 116:1853-1864. doi:10.1172/JCI27438

4. Bell JR, Raaijmakers AJA, Curl CL, Reichelt ME, Harding TW, Bei A, Ng DCH, Erickson JR, Petroff MV, Harrap SB, Delbridge LMD (2015) Cardiac CaMKII $\delta$ splice variants exhibit target signaling specificity and confer sex-selective arrhythmogenic actions in the ischemic-reperfused heart. Int $\mathbf{J}$ Cardiol 181:288-296. doi:10.1016/j.ijcard.2014.11.159

5. Chu G, Kranias EG (2002) Functional interplay between dual site phospholambam phosphorylation: insights from genetically altered mouse models. Basic Res Cardiol 97(Suppl 1):I43-I48

6. Duan DD (2015) Calm down when the heart is stressed-inhibiting calmodulin-dependent protein kinase II for antiarrhythmias. Trends Cardiovasc Med 25:398-400. doi:10.1016/j.tcm. 2015.01.016

7. Erickson JR, Joiner M-LA, Guan X, Kutschke W, Yang J, Oddis CV, Bartlett RK, Lowe JS, O’Donnell SE, Aykin-Burns N, Zimmerman MC, Zimmerman K, Ham A-JL, Weiss RM, Spitz DR, Shea MA, Colbran RJ, Mohler PJ, Anderson ME (2008) A dynamic pathway for calcium-independent activation of CaMKII by methionine oxidation. Cell 133:462-474. doi:10.1016/j.cell.2008.02.048

8. Erickson JR, Nichols CB, Uchinoumi H, Stein ML, Bossuyt J, Bers DM (2015) $S$-Nitrosylation induces both autonomous activation and inhibition of calcium/calmodulin-dependent protein kinase II $\delta$. J Biol Chem 290:25646-25656. doi:10.1074/jbc. M115.650234

9. Erickson JR, Pereira L, Wang L, Han G, Ferguson A, Dao K, Copeland RJ, Despa F, Hart GW, Ripplinger CM, Bers DM (2013) Diabetic hyperglycaemia activates CaMKII and arrhythmias by $O$-linked glycosylation. Nature $502: 372-376$. doi:10. 1038/nature 12537

10. Gray CBB, Heller Brown J (2014) CaMKIIdelta subtypes: localization and function. Front Pharmacol 5:15. doi:10.3389/ fphar.2014.00015 (eCollection 2014)

11. Greenberg B, Yaroshinsky A, Zsebo KM, Butler J, Felker GM, Voors AA, Rudy JJ, Wagner K, Hajjar RJ (2014) Design of a phase $2 b$ trial of intracoronary administration of AAV1/SERCA2a in patients with advanced heart failure. JACC Heart Fail 2:84-92. doi:10.1016/j.jchf.2013.09.008

12. Gutierrez DA, Fernandez-Tenorio M, Ogrodnik J, Niggli E (2013) NO-dependent CaMKII activation during $\beta$-adrenergic stimulation of cardiac muscle. Cardiovasc Res 100:392-401. doi:10.1093/cvr/cvt201

13. He BJ, Joiner M-LA, Singh MV, Luczak ED, Swaminathan PD, Koval OM, Kutschke W, Allamargot C, Yang J, Guan X, Zimmerman K, Grumbach IM, Weiss RM, Spitz DR, Sigmund CD, Blankesteijn WM, Heymans S, Mohler PJ, Anderson ME (2011) Oxidation of CaMKII determines the cardiotoxic effects of aldosterone. Nat Med 17:1610-1618. doi:10.1038/nm.2506

14. Hegyi B, Chen-Izu Y, Jian Z, Shimkunas R, Izu LT, Banyasz T (2015) KN-93 inhibits IKr in mammalian cardiomyocytes. J Mol Cell Cardiol 89:173-176. doi:10.1016/j.yjmcc.2015.10.012
15. Heijman J, Dobrev D (2015) Irregular rhythm and atrial metabolism are key for the evolution of proarrhythmic atrial remodeling in atrial fibrillation. Basic Res Cardiol 110:1-5. doi:10. 1007/s00395-015-0498-1

16. Hudmon A, Schulman H (2002) Structure-function of the multifunctional $\mathrm{Ca}^{2+} /$ calmodulin-dependent protein kinase II. Biochem J 364:593-611. doi:10.1042/BJ20020228

17. Hund TJ, Mohler PJ (2015) Role of CaMKII in cardiac arrhythmias. Trends Cardiovasc Med 25:392-397. doi:10.1016/j.tcm. 2014.12.001

18. Iwasa $\mathrm{T}$, Inoue $\mathrm{N}$, Miyamoto $\mathrm{E}$ (1985) Identification of a calmodulin-dependent protein kinase in the cardiac cytosol, which phosphorylates phospholamban in the sarcoplasmic reticulum. J Biochem 98(2):577-580

19. Kreusser MM, Lehmann LH, Wolf N, Keranov S, Jungmann A, Gröne H-J, Müller OJ, Katus HA, Backs J (2016) Inducible cardiomyocyte-specific deletion of CaM Kinase II protects from pressure-overload-induced heart failure. Basic Res Cardiol. doi:10.1007/s00395-016-0581-2

20. Lai NC (2004) Intracoronary adenovirus encoding adenylyl cyclase VI increases left ventricular function in heart failure. Circulation 110:330-336. doi:10.1161/01.CIR.0000136033. 21777.4D

21. Lenski M, Schleider G, Kohlhaas M, Adrian L, Adam O, Tian Q, Kaestner L, Lipp P, Lehrke M, Maack C, Böhm M, Laufs U (2015) Arrhythmia causes lipid accumulation and reduced glucose uptake. Basic Res Cardiol 110:1-19. doi:10.1007/s00395015-0497-2

22. Lorenz K, Stathopoulou K, Schmid E, Eder P, Cuello F (2014) Heart failure-specific changes in protein kinase signalling. Pflugers Arch 466:1151-1162. doi:10.1007/s00424-014-1462-X

23. Lu Y-M, Huang J, Shioda N, Fukunaga K, Shirasaki Y, Li X-M, Han F (2011) CaMKIISB mediates aberrant NCX1 expression and the imbalance of NCX1/SERCA in transverse aortic constriction-induced failing heart. PLoS One 6:e24724-e24812. doi:10.1371/journal.pone.0024724

24. Macdonnell SM, Weisser-Thomas J, Kubo H, Hanscome M, Liu Q, Jaleel N, Berretta R, Chen X, Brown JH, Sabri A-K, Molkentin JD, Houser SR (2009) CaMKII negatively regulates calcineurin-NFAT signaling in cardiac myocytes. Circ Res 105:316-325. doi:10.1161/CIRCRESAHA.109.194035

25. Magupalli VG, Mochida S, Yan J, Jiang X, Westenbroek RE, Nairn AC, Scheuer T, Catterall WA (2013) $\mathrm{Ca}^{2+}$-independent activation of $\mathrm{Ca}^{2+} /$ calmodulin-dependent protein kinase II bound to the C-terminal domain of CaV2.1 calcium channels. J Biol Chem 288:4637-4648. doi:10.1074/jbc.M112.369058

26. Maier LS, Bers DM (2007) Role of $\mathrm{Ca}^{2+} /$ calmodulin-dependent protein kinase $(\mathrm{CaMK})$ in excitation-contraction coupling in the heart. Cardiovasc Res 73:631-640. doi:10.1016/j.cardiores.2006. 11.005

27. Mesubi OO, Anderson ME (2016) Atrial remodelling in atrial fibrillation: CaMKII as a nodal proarrhythmic signal. Cardiovasc Res 109:542-557. doi:10.1093/cvr/cvw002

28. Mishra S, Gray CBB, Miyamoto S, Bers DM, Brown JH (2011) Location matters: clarifying the concept of nuclear and cytosolic CaMKII subtypes. Circ Res 109:1354-1362. doi:10.1161/CIR CRESAHA.111.248401

29. Mollova MY, Katus HA, Backs J (2015) Regulation of CaMKII signaling in cardiovascular disease. Front Pharmacol 6:468-478. doi:10.3389/fphar.2015.00178

30. Pellicena P, Schulman H (2014) CaMKII inhibitors: from research tools to therapeutic agents. Front Pharmacol 5:21. doi:10.3389/fphar.2014.00021

31. Pleger ST, Raake P, Katus HA, Most P (2014) Cardiac calcium handling on trial: targeting the failing cardiomyocyte 
signalosome. Circ Res 114:12-14. doi:10.1161/CIRCRESAHA. 113.302748

32. Purohit A, Purohit A, Rokita AG, Rokita AG, Guan X, Guan X, Chen B, Chen B, Koval OM, Koval OM, Voigt N, Voigt N, Neef S, Neef S, Sowa T, Sowa T, Gao Z, Gao Z, Luczak ED, Luczak ED, Stefansdottir H, Stefansdottir H, Behunin AC, Behunin AC, Li N, Li N, El-Accaoui RN, El-Accaoui RN, Yang B, Yang B, Swaminathan PD, Swaminathan PD, Weiss RM, Weiss RM, Wehrens XHT, Wehrens XHT, Song L-S, Song LS, Dobrev D, Dobrev D, Maier LS, Maier LS, Anderson ME, Anderson ME (2013) Oxidized $\mathrm{Ca}(2+) /$ calmodulin-dependent protein kinase II triggers atrial fibrillation. Circulation 128:1748-1757. doi:10.1161/CIRCU LATIONAHA.113.003313

33. Rincon MY, VandenDriessche T, Chuah MK (2015) Gene therapy for cardiovascular disease: advances in vector development, targeting, and delivery for clinical translation. Cardiovasc Res 108:4-20. doi:10.1093/cvr/cvv205

34. Rodriguez P, Bhogal MS, Colyer J (2003) Stoichiometric phosphorylation of cardiac ryanodine receptor on serine 2809 by calmodulin-dependent kinase II and protein kinase A. J Biol Chem 278:38593-38600. doi:10.1074/jbc.C301180200

35. Rohde D, Busch M, Volkert A, Ritterhoff J, Katus HA, Peppel K, Most P (2015) Cardiomyocytes, endothelial cells and cardiac fibroblasts: S100A1's triple action in cardiovascular pathophysiology. Future Cardiology 11:309-321. doi:10.2217/fca.15.18

36. Rohde D, Ritterhoff J, Voelkers M, Katus HA, Parker TG, Most P (2010) S100A1: a multifaceted therapeutic target in cardiovascular disease. J Cardiovasc Transl Res 3:525-537. doi:10.1007/ s12265-010-9211-9

37. Sadayappan S, Gulick J, Osinska H, Barefield D, Cuello F, Avkiran M, Lasko VM, Lorenz JN, Maillet M, Martin JL, Brown JH, Bers DM, Molkentin JD, James J, Robbins J (2011) A critical function for Ser-282 in cardiac Myosin binding protein-C phosphorylation and cardiac function. Circ Res 109:141-150. doi:10. 1161/CIRCRESAHA.111.242560
38. Schmid E, Neef S, Berlin C, Tomasovic A, Kahlert K, Nordbeck P, Deiss K, Denzinger S, Herrmann S, Wettwer E, Weidendorfer M, Becker D, Schäfer F, Wagner N, Süleymann E, Schmitt JP, Katus HA, Weidemann F, Ravens U, Maack C, Hein L, Ertl G, Müller OJ, Maier LS, Lohse MJ, Lorenz K (2015) Cardiac RKIP induces a beneficial $\beta$-adrenoceptor-dependent positive inotropy. Nat Med. doi:10.1038/nm.3972

39. Uchinoumi H, Yang Y, Oda T, Li N, Alsina KM, Puglisi JL, Chen-Izu Y, Cornea RL, Wehrens XHT, Bers DM (2016) CaMKII-dependent phosphorylation of RyR2 promotes targetable pathological RyR2 conformational shift. J Mol Cell Cardiol 98:62-72. doi:10.1016/j.yjmcc.2016.06.007

40. Wang W-Y, Hao L-Y, Minobe E, Saud ZA, Han D-Y, Kameyama M (2009) CaMKII phosphorylates a threonine residue in the C-terminal tail of Cav1.2 $\mathrm{Ca}^{2+}$ channel and modulates the interaction of the channel with calmodulin. J Physiol Sci 59:283-290. doi:10.1007/s12576-009-0033-y

41. Wehrens XHT (2004) $\mathrm{Ca}^{2+} /$ calmodulin-dependent protein kinase II phosphorylation regulates the cardiac ryanodine receptor. Circ Res 94:e61-e70. doi:10.1161/01.RES.0000125626.33738.E2

42. Westenbrink BD, Edwards AG, McCulloch AD, Brown JH (2013) The promise of CaMKII inhibition for heart disease: preventing heart failure and arrhythmias. Expert Opin Ther Targets 17:889-903. doi:10.1517/14728222.2013.809064

43. Zhang $\mathrm{T}$ (2003) The deltaC isoform of CaMKII Is activated in cardiac hypertrophy and induces dilated cardiomyopathy and heart failure. Circ Res 92:912-919. doi:10.1161/01.RES. 0000069686.31472.C5

44. Zhang T, Heller Brown J (2004) Role of $\mathrm{Ca}^{2+} /$ calmodulin-dependent protein kinase II in cardiac hypertrophy and heart failure. Cardiovasc Res 63:476-486. doi:10.1016/j.cardiores.2004.04.026

45. Zhang T, Zhang Y, Cui M, Jin L, Wang Y, Lv F, Liu Y, Zheng W, Shang H, Zhang J, Zhang M, Wu H, Guo J, Zhang X, Hu X, Cao C-M, Xiao R-P (2016) CaMKII is a RIP3 substrate mediating ischemia- and oxidative stress-induced myocardial necroptosis. Nat Med 22:175-182. doi:10.1038/nm.4017 